\title{
Підходи до розробки референтних рівнів західноєвропейської асоціації органів регулювання ядерної безпеки (WENRA) для дослідницьких реакторів
}

- Шепітчак Андрій Васильович

Державна інспекція ядерного регулювання України, м. Київ, Україна ORCID: https://orcid.org/0000-0003-4469-9653

- Кухоцький Олександр Васильович, канд. техн. наук Державне підприємство «Державний науково-технічний центр з ядерної та радіаційної безпеки», м. Київ, Україна ORCID: https://orcid.org/0000-0002-0909-511X

\section{- Лігоцький Олексій Ігорович}

Державне підприємство «Державний науково-технічний центр з ядерної та радіаційної безпеки», м. Київ, Україна ORCID: https://orcid.org/0000-0001-7487-2811

\section{- Кульман Олексій Миколайович}

Державне підприємство «Державний науково-технічний центр з ядерної та радіаційної безпеки», м. Київ, Україна ORCID: https://orcid.org/0000-0002-7280-3174

Тимчасова робоча група з розробки референтних рівнів для дослідницьких ядерних реакторів «WENRA Ad Hoc Working Group on Reference Levels for Research Reactors» (WGRR) була сформована у рамках ініціативи Західноєвропейської асоціації органів регулювання ядерної безпеки (WENRA) у квітні 2017 року. Україна, як член WENRA, долучилася до робочої групи в складі експертів Державної інспекції ядерного регулювання України та Державного підприємства «Державний науково-технічний центр з ядерної та радіаційної безпеки». Основною метою діяльності робочої групи WGRR була розробка референтних рівнів для діючих дослідницьких ядерних реакторів з метою подальшої гармонізації вимог країн-членів WENRA. Це перша стаття із серії статей за напрямом гармонізації вимог для дослідницьких реакторів. У цій статті авторами наведено передумови створення робочої групи WGRR, визначення ї̈ основного завдання та підходи до розробки референтних рівнів.

Ключові слова: WENRA, безпека, вимоги, дослідницькі реактори, ядерна установка.

() Шепітчак А. В., Кухоцький О. В., Лігоцький О. І., Кульман О. М., 2021

Західноєвропейська асоціація регулюючих органів з ядерної безпеки (WENRA) $\epsilon$ провідною європейською організацією органів регулювання ядерної та радіаційної безпеки країн-членів Європейського союзу (ЄС) з розробки єдиних стандартів регулювання ядерної та радіаційної безпеки всередині $\in C$, а також $з$ напрацювання умов забезпечення ядерної безпеки в країнах, які планують стати членами $\in C$. Україна бере активну участь у діяльності WENRA з 2009 року після набуття статусу спостерігача WENRA. У березні 2015 року Україна стала першою країною не $\in C$, що набула статусу повноправного члена WENRA. Державна інспекція ядерного регулювання 
України (Держатомрегулювання) $\epsilon$ учасником пленарнихзасіданьWENRA,урамкахякихвисловлює позицію щодо стратегії та планів діяльності асоціації [1]. Представники Держатомрегулювання із залученням провідних експертів Державного підприємства «Державний науково-технічний центр з ядерної та радіаційної безпеки» (ДНТЦ ЯРБ)) беруть учать удіяльності та засіданнях робочих груп WENRA (Reactor Harmonisation Working Group (RHWG), Working Group on Waste and Decommissioning (WGWD), Working Group on Research Reactors (WGRR)), де обговорюються питання гармонізації європейських регулюючих вимог, розробляються документи та настанови щодо окремих технічних питань забезпечення ядерної безпеки (вимоги до нових АЕС, довгострокова експлуатація, періодична переоцінка безпеки, перегляд референтних рівнів 3 безпеки тощо (Рисунок 1).

3 метою забезпечення ефективної участі Держатомрегулювання в діяльності WENRA створена Комісія Держатомрегулювання 3 питань гармонізації національних норм і правил 3 ядерної та радіаційної безпеки України до референтних рівнів WENRA, яку очолює Голова Держатомрегулювання - Головний державний інспектор з ядерної та радіаційної безпеки. 3 часу набуття Україною членства у WENRA, питання гармонізації національних регулюючих вимог 3 ядерної та радіаційної безпеки $з$ референтними рівнями WENRA $\epsilon$ одним із пріоритетних напрямів діяльності Держатомрегулювання [1].

\section{Робоча група з розробки референтних рівнів безпеки для дяу}

Відповідно до бази даних Міжнародного агентства з атомної енергії (МАГАТЕ) щодо дослідницьких реакторів [2] у світі станом на 2021 рік налічується 222 дослідницькі ядерні установки (ДЯУ), що експлуатуються, 14 - тимчасово зупинені та 12 - на етапі будівництва чи зняття з експлуатації. МАГАТЕ на постійній основі здійснює діяльність з розробки та імплементації вимог з безпеки для дяу, втім вимоги МАГАТЕ мають рекомендаційний характер і регулюючі органи країн самостійно вирішують щодо їх врахування під час розробки національних регулюючих вимог з безпеки ДЯУ. Такий підхід $\epsilon$ прийнятним, проте призводить до відмінності вимог з безпеки ДЯУ навіть країн-членів ЄС. До сьогодні вимоги для цих установок не були об'єктом гармонізації. На 31 засіданні Європейської групи регуляторів ядерної безпеки (ENSREG) було висунуто ініціативу щодо необхідності розширення діяльності і на інші ядерні установки крім атомних електростанцій (AEC) [3].

На виконання цієї ініціативи, під час весняної зустрічі у Відні 2016 року, WENRA було ухвалено рішення про розроблення референтних рівнів безпеки для дяУ за допомогою створення «спеціальної» тимчасової робочої групи WENRA (WGRR). Очолив цю групу Нідерландський регулюючий орган 3 ядерної безпеки (ANVS). у березні 2017 року секретаріат WENRA направив запити про призначення членів групи до Бельгії, Франції і Німеччини та запропонував іншим країнам приєднатися до цієї групи. Приєдналися ще чотири країни: Угорщина, Норвегія, Польща та Україна. До WGRR увійшли 11 учасників 38 країн. Україна, як член WENRA, долучилася до робочої групи в складі експертів Держатомрегулювання та ДНТЦ ЯРБ. Група розпочала роботу в першій половині 2017 року (перше засідання відбулося в червні 2017 року). Основним завданням групи стала розробка референтних рівнів безпеки для дяу.

\section{Розробка референтних рівнів безпеки для дяу}

Під час розробки референтних рівнів безпеки для дяу за основу були взяті референтні рівні безпеки для діючих реакторів AEC (редакція 2014 року) [4], оновлені з метою врахування уроків, винесених з аварії на АЕС Фукусіма-1. Було вирішено, що обсяг напрямів (англ. «Issues») peферентних рівнів безпеки для дяУ повинен узгоджуватися 3 відповідними напрямами [4] та можливістю їх доповнення новими напрацюваннями RHWG та специфічними для ДяУ напрямами.

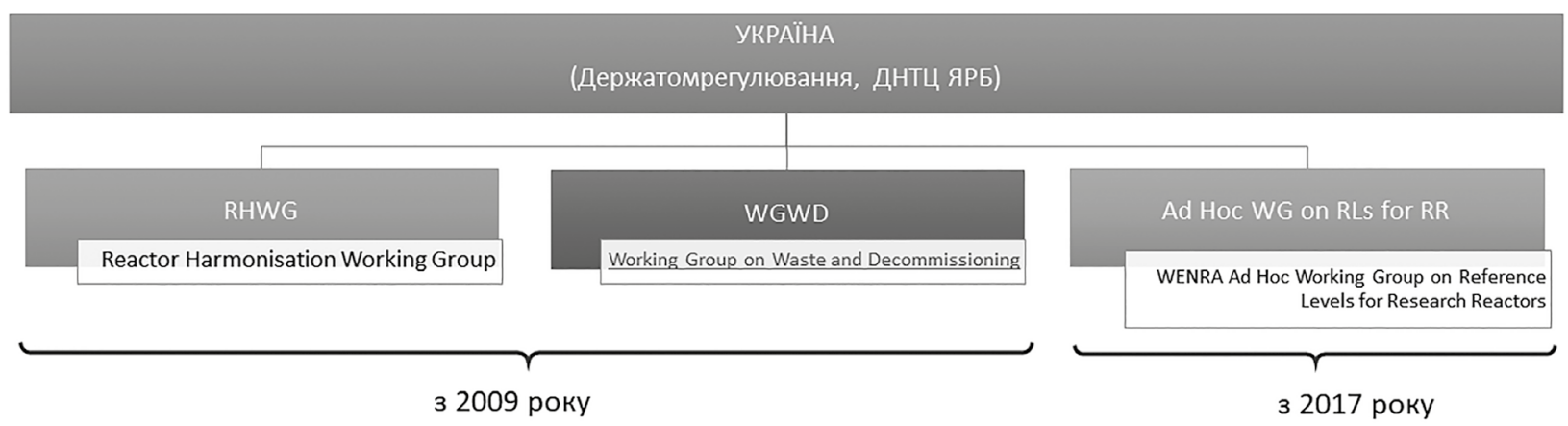

Рисунок 1 - Участь України в робочих групах 
Як і для AEC, референтні рівні безпеки для дяУ також не мають охоплювати питань захищеності, радіаційного захисту, поводження з відходами, склад активної зони тощо). Внеском до референтних рівнів ДяУ, який визначає особливості та специфіку Дяу, будуть національні вимоги країн учасниць та стандарти МАГАТЕ. Розробка референтних рівнів безпеки для ДЯУ виконувалась у чотири етапи:

1) оцінка застосовності [4] для дяУ та їх модифікація;

2) розробка специфічних референтних рівнів безпеки для дяу;

3) перевірка референтних рівнів безпеки та зворотній зв'язок;

4) остаточне погодження та розробка додаткових матеріалів.

Сфера застосування референтних рівнів. На початку розробки референтних рівнів для дяу першочерговим завдання було «обмежити обсяг застосування референтних рівнів». Для розв'язання цього завдання за основу взятий перелік Дяу, сформований RHWG для Тематичної партнерської перевірки за напрямом «Управління старінням» (Topical Peer Review on Ageing Management). Проте, щодо цього переліку виникла певна плутанина, оскільки було незрозуміло, зважаючи на які характеристики ДЯУ він базується (потужність, сфера використання, тип чи ін.). Учасниками групи ухвалено рішення щодо перегляду цього переліку з урахуванням бази дяУ МАГАТЕ [2] та створено окрему базу ДЯУ, особливістю якої $\epsilon$ вказівки щодо
Таблиця 1 - Категоризація дяу

\begin{tabular}{|c|c|}
\hline Критерій & $\begin{array}{c}\text { Категорія } \\
\text { Дяу }\end{array}$ \\
\hline $\begin{array}{l}\text { ДЯУ потужністю > } 1 \mathrm{MBт}_{\text {теп, }} \text { та ДЯУ } \\
\text { потужністю } \leq 1 \mathrm{MBT}_{\text {теп' }} \text { зі значним } \\
\text { додатковим ризиком }\end{array}$ & 1 \\
\hline $\begin{array}{l}\text { ДЯУ потужністю } \leq 1 \text { МВт }_{\text {теп, }} \text { які не } \\
\text { мають додаткового значного ризику }\end{array}$ & 2 \\
\hline
\end{tabular}

членства країни у WENRA та ENSREG, а також типу теплоносія (див. приклад бази на Рисунку 2).

у першому проєкті під час розробки референтних рівнів безпеки для дяУ прийнято дві категорії установок, які характеризуються потужністю, і застосовано обмеження в 1 МВт $_{\text {теп }}$ та охоплено лише ДЯУ, які експлуатуються.

Втім ця категоризація виявилася обмеженою через різні типи ядерних установок. Для розширення категоризації розглянуто класифікацію відповідно загальних вимог безпеки GSR-7 [5] МАГАTE та Додатка 3 до SSG-22 [6] щодо аварійної готовності. У результаті ухвалено рішення про застосування двох категорій, з можливістю для регулюючого органу категоризації установок 3 урахуванням додаткового ризику ДяУ (Таблиця 1). Під додатковим ризиком прийняті критерії згідно з п.2.7 SSG-22 [6], наприклад: теплова потужність, джерела іонізуючого випромінювання, збагачення та кількість палива, наявність чи відсутність систем охолодження під тиском тощо.

\begin{tabular}{|c|c|c|c|c|c|c|c|}
\hline Kраїна & Назва Дяу & Тип & $\begin{array}{c}\text { Теплова } \\
\text { потужність, } \\
\text { МВт }\end{array}$ & Статус & WENRA & ENSREG & Тип т/н \\
\hline$\ldots$ & & & & & & & \\
\hline Ukraine & Multipurpose RR & POOL & 20 & PLANNED & member & no-EU & light water \\
\hline Germany & FRM II & POOL & 20 & OPERATIONAL & member & EU & light water \\
\hline France & ORPHEE & POOL & 14 & OPERATIONAL & member & EU & light water \\
\hline Germany & BER-II & POOL & 10 & OPERATIONAL & member & EU & light water \\
\hline Ukraine & WWR-M KIEV & TANK WWR & 10 & OPERATIONAL & member & no-EU & light water \\
\hline Belgium & BR-1 & GRAPHITE & 1 & OPERATIONAL & member & EU & air \\
\hline France & ISIS & POOL & 0.7 & OPERATIONAL & member & EU & light water \\
\hline Germany & FRMZ & TRIGA MARK II & 0.1 & OPERATIONAL & member & EU & light water \\
\hline France & MASURCA & CRIT FAST & 0.005 & $\begin{array}{c}\text { TEMPORARY } \\
\text { SHUTDOWN }\end{array}$ & member & EU & air \\
\hline Belgium & VENUS & $\begin{array}{c}\text { FAST } \\
\text { (CRIT or ADS) }\end{array}$ & below $10 \wedge-3$ & OPERATIONAL & member & EU & none \\
\hline Ukraine & $\begin{array}{c}\text { KIPT } \\
\text { Experimental } \\
\text { Neutron Source }\end{array}$ & SUBCRIT & 0.36 & UNDER & member & no-EU & light water \\
\hline France & MINERVE & POOL & 0.0001 & OPERATIONAL & member & EU & light water \\
\hline$\ldots$ & $\ldots$ & & & & & & \\
\hline
\end{tabular}

Рисунок 2 - База дяу Європи 
Після остаточно сформованого набору референтних рівнів для ДяУ визначено, що кількість референтних рівнів, які не поширюються на всі ДяУ, була дуже обмеженою, і тому було вирішено спростити ситуацію за допомогою адаптації цих референтних рівнів так, щоб вони також застосовувались до всіх Дяу.

3 огляду на різні типи існуючих ДЯУ, а також ураховуючи, що вони можуть становити дуже різні ризики для персоналу, населення та навколишнього середовища, існує необхідність диференційованого підходу під час застосування референтних рівнів безпеки. Дійсно, референтні рівні безпеки не можуть бути застосовні для кожної дяУ однаково, наприклад, для дослідницьких реакторів з високою тепловою потужністю, для яких фізично можливе пошкодження активної зони можуть застосовуватись деякі референтні рівні як і для АEC, тоді як ті ж референтні рівні безпеки можуть здаватися надмірно високими для дослідницьких реакторів 3 низькою тепловою потужністю, і для яких пошкодження активної зони практично унеможливлене. Тому, остаточна сфера застосування референтних рівнів для дяу охоплює всі типи дослідницьких реакторів, за винятком критичних та підкритичних збірок, гомогенних реакторів нульової потужності та прискорювальних систем. Під час застосування референтних рівнів для діючих дослідницьких реакторів необхідно враховувати диференційований підхід, як описано в Додатку А [11].

Оцінка застосовності [4] для дослідницьких реакторів та їх модифікація. Розробка референтних рівнів безпеки для дослідницьких реакторів була розпочата $з$ оцінки застосовності 342 референтних рівнів [4] для дослідницьких реакторів 3 урахуванням прийнятої категоризації. 342 референтні рівні [4] було розподілено між країнами-учасниками групи (Таблиця 2) та розпочато їх оцінку.

Таблиця 2 - Розподіл референтних рівнів [4]

\begin{tabular}{|c|c|c|c|c|}
\hline \multicolumn{2}{|r|}{ Група референтних рівнів безпеки } & \multirow{3}{*}{$\begin{array}{c}\text { Країна } \\
\text { Угорщина }\end{array}$} & \multicolumn{2}{|c|}{$\begin{array}{c}\text { Кількість референтних } \\
\text { рівнів безпеки }\end{array}$} \\
\hline & & & легкі* & важкі* \\
\hline A & Політика з безпеки & & 9 & \\
\hline B & Експлуатуюча організація & Норвегія & 15 & \\
\hline C & Керывництво та управління з питань безпеки & Норвегія & 26 & \\
\hline $\mathrm{D}$ & $\begin{array}{c}\text { Підготовка та ліцензування персоналу дослідницьких } \\
\text { реакторів }\end{array}$ & Бельгія & 15 & \\
\hline $\mathrm{E}$ & Проєктні основи для діючих дослідницьких реакторів & Україна & & 46 \\
\hline $\mathrm{F}$ & Розширення проекту для діючих дослідницьких реакторів & Франція & & 25 \\
\hline G & Класифікація з безпеки структур, систем та елементів & Бельгія & & 7 \\
\hline $\mathrm{H}$ & Межі та умови експлуатації & Польща & 19 & \\
\hline I & Управління старінням & Німеччина & 8 & \\
\hline J & $\begin{array}{c}\text { Система розслідування порушень та обмін досвідом } \\
\text { експлуатації }\end{array}$ & Німеччина & 16 & \\
\hline $\mathrm{K}$ & Ремонт, перевірки та випробування & Польща & 20 & \\
\hline LM & $\begin{array}{c}\text { Процедури з управління аваріями та керівництва } 3 \\
\text { управління важкими аваріями }\end{array}$ & Бельгія & & 20 \\
\hline $\mathrm{N}$ & Зміст та оновлення звіту з аналізу безпеки (ЗАБ) & Угорщина & & 17 \\
\hline $\mathrm{O}$ & Імовірнісний аналіз безпеки (ІАБ) & Угорщина & & 16 \\
\hline$P$ & Періодична переоцінка безпеки (ЗППБ) & Нідерланди & 5 & \\
\hline Q & Модифікації дослідницьких реакторів & Нідерланди & 15 & \\
\hline $\mathrm{R}$ & Аварійна готовність на майданчику & Німеччина & & 20 \\
\hline $\mathrm{S}$ & Захист від внутрішніх пожеж & Нідерланди & & 20 \\
\hline $\mathrm{T}$ & Природні впливи & Франція & & 19 \\
\hline
\end{tabular}

* $з$ огляду на складність аналізу референтних рівнів 
Для документування оцінки було прийнято таку категоризацію:

«A» - референтні рівні, застосовні для дослідницьких реакторів без або з незначними правками;

«В» - референтні рівні, застосовні для дослідницьких реакторів зі значними правками та модифікаціями;

«С» - референтні рівні, не застосовні для дослідницьких реакторів.

Україна виконувала оцінку референтних рівнів групи $\mathrm{E}$ «Design Basis Envelope for Existing Reactors».

Під час другої зустрічі, яка відбулася у вересні 2017 року [7], було обговорено результати оцінки 342 референтних рівнів [4] 3 огляду на їх застосовність для дослідницьких реакторів. За результатами обговорення було визначено, що 30 референтних рівнів безпеки отримали оцінку «В» для всіх дослідницьких реакторів, 3 - оцінку «С» для всіх дослідницьких реакторів $\mathrm{i}$ «A» для дослідницьких реакторів потужністю >1 МВт, а також 3 - оцінку «С» для всіх дослідницьких реакторів і «В» для дослідницьких реакторів потужністю > 1 МВт. Це призвело до попереднього висновку, що майже $90 \%$ референтних рівнів безпеки, визначені для АEC [4], можуть застосовуватися також і для всіх дослідницьких реакторів. Під час наступних засідань WGRR обговорення було зосереджено на розгляді 36 референтних рівнів у частині розробки змін або пропозицій щодо альтернативних трактувань.

Розробка специфічних референтних рівнів для дослідницьких реакторів виконувалась за допомогою аналізу нормативної бази країнчленів групи та вимог МАГАТЕ для дослідницьких реакторів. Основна увага була зосереджена на стандарті з безпеки MAГATE SSR-3 [8]. Представниками України був проаналізований зазначений стандарт [8] та визначені специфічні для ДЯУ аспекти (вимоги), якими мають бути доповненні референтні рівні для дяУ, а саме: вимоги до експериментальних пристроїв та експериментів; вимоги для довготривалих та тимчасових зупинів; зміни складу активної зони; критерії диференційованого підходу. В результаті набір референтних рівнів було доповнено специфічними для дослідницьких реакторів аспектами, зокрема, окремою групою референтних рівнів «Експериментальні пристрої та експерименти» - група «X». Проєкт референтних рівнів цієї групи було розроблено представниками України. У січні 2019 року отримано перший проєкт референтних рівнів для дослідницьких реакторів та розпочато етап їх перевірки.

Перевірка референтних рівнів безпеки та зворотній зв'язок. Перший проєкт референтних рівнів для дослідницьких реакторів був додатково перевірений членами групи згідно з політикою WENRA і практикою RHWG, після чого був надісланий для «зовнішнього» відгуку МАГАТЕ, всім ліцензіатам дослідницьких реакторів країнчленів групи та іншим країнам-членам WENRA, що експлуатують ДЯУ, зокрема, Греції, Італії, Румунії, Словенії, а також регулюючому органу Великої Британії за їх запитом. У результаті було отримано 233 коментарі з 27 організацій (Рисунок 3) та розпочато процес винесення резолюцій за коментарями і коригування референтних рівнів, за необхідності.

Розгляд отриманих коментарів та винесення резолюцій виконувався відповідно до такого підходу перехресної перевірки:
Кількість коментарів за групами референтних рівнів

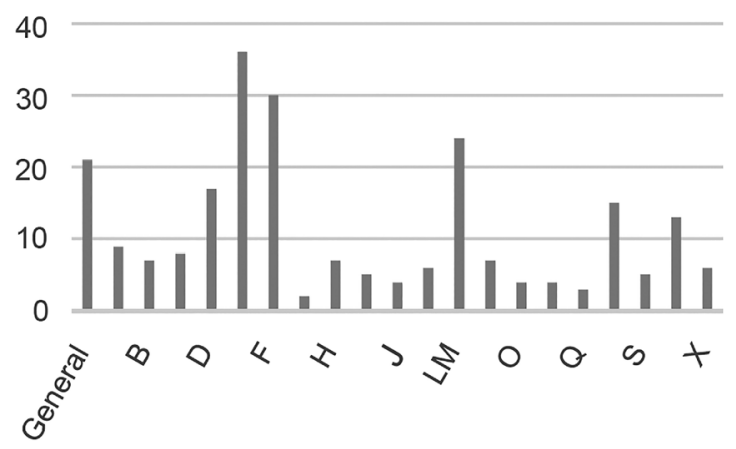

Кількість коментарів за країнами та організаціями

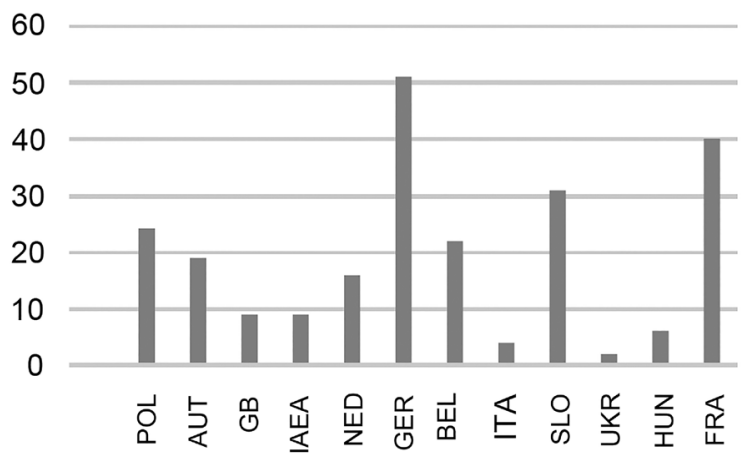

Рисунок 3 - Розподіл коментарів за групами референтних рівнів безпеки та країнами 
Таблиця 3 - Організація винесення резолюцій на коментарі

\begin{tabular}{|c|l|c|c|}
\hline \multirow{2}{*}{ № підгрупи } & \multicolumn{1}{|c|}{ Країни } & Групи референтних рівнів & $\begin{array}{c}\text { № перевірочної } \\
\text { групи }\end{array}$ \\
\hline 1 & Україна, Польща & $\mathrm{E}, \mathrm{H}, \mathrm{K}, \mathrm{X}$ & 5 \\
\hline 2 & Франція, Австрія & $\mathrm{F}, \mathrm{T}$ & 1 \\
\hline 3 & Бельгія, Нідерланди & $\mathrm{D}, \mathrm{G}, \mathrm{LM}, \mathrm{P}, \mathrm{Q}, \mathrm{S}$ & 2 \\
\hline 4 & Німеччина, Угорщина & $\mathrm{A}, \mathrm{I}, \mathrm{J}, \mathrm{N}, \mathrm{O}, \mathrm{R}$ & 3 \\
\hline 5 & Норвегія, Чеська Республіка & $\mathrm{B}, \mathrm{C}$ & 4 \\
\hline
\end{tabular}

учасники групи об'єднані в підгрупи та виконують розгляд коментарів i готують резолюції для груп референтних рівнів, закріплених за ними на попередньому етапі (наприклад, Україна відповідальна за групи референтних рівнів «Е» та «X», Польща за групи «Н» та «К» - відповідно група «Україна-Польща» розглядає коментарі та готує резолюції для груп референтних рівнів «Е», «Н», «К», «Х») (Таблиця 3);

резолюції направляються до іншої підгрупи для перевірки. Резолюції, які потребують подальшого обговорення, маркуються;

перевірені резолюції 3 маркованими для подальшого обговорення направляються секретарю групи для формування загального документа резолюцій.

Унаслідок такої перехресної перевірки лише 44 резолюції/коментарі 3233 винесені для обговорення на технічній зустрічі WGRR для ухвалення остаточного рішення.

Остаточне погодження та розробка додаткових матеріалів. Остаточний документ референтних рівнів безпеки для діючих дослідницьких реакторів ухвалений на 9 засіданні WGRR [8]. Додатково до набору референтних рівнів для дослідницьких реакторів внесені останні оновлення, опубліковані RHWG [10], щодо референтних рівнів групи «С» - «Система управління» та «|» - «Управління старінням». В результаті отримано набір 3331 референтних рівнів безпеки для діючих дослідницьких реакторів (Таблиця 4).

Крім референтних рівнів безпеки для дослідницьких реакторів WGRR здійснювалася розробка окремого глосарію термінів у межах референтних рівнів безпеки для діючих дослідницьких реакторів, керівництво для групи референтних рівнів «О» - «Імовірнісний аналіз безпеки», керівництво із застосування диференційованого підходу під час впровадження референтних рівнів безпеки для діючих дослідницьких реакторів.

Глосарій термінів визначає ключові терміни, які використовуються в референтних рівнях безпеки для ДяУ з метою гармонізації термінології в межах референтних рівнів. Розробка глосарію пов'язана 3 тим, що референтні рівні для дослідницьких реакторів базуються на [4], що спричиняє їх некоректне розуміння з огляду на сфери використання дослідницьких реакторів, персоналу тощо.

Оскільки імовірнісний аналіз безпеки для дослідницьких реакторів $\epsilon$ додатковим та/ або рекомендаційним, запропоновано окреме керівництво у разі його виконання. Зазначене керівництво містить роз'яснення щодо очікувань у разі виконання імовірнісного аналізу безпеки дослідницьких реакторів, його розробки та використання результатів.

\section{Висновки}

Референтні рівні безпеки для діючих дослідницьких реакторів [11] опубліковані WENRA 18 грудня 2020 року. Завдяки успішному виконанню поставленого завдання, тимчасово створена робоча група WGRR набула статусу постійно діючої групи WENRA. Наступним завданням групи та країн-членів WENRA $\epsilon$ гармонізація національних вимог для дослідницьких реакторів та відповідно поліпшення безпеки в країнах-членах WENRA за напрямом «Безпека дослідницьких реакторів».

Це $\epsilon$ першою статтею серії, надалі буде наведено аналіз та особливості референтних рівнів безпеки для дослідницьких реакторів. 
Шепітчак А. В., Кухоцький О. В., Лігоцький О. І., Кульман О. М.

Таблиця 4 - Зміна кількості референтних рівнів під час розробки

\begin{tabular}{|c|c|c|c|c|c|c|c|}
\hline \multirow{2}{*}{$\begin{array}{c}\text { Група } \\
\text { референтних } \\
\text { рівнів }\end{array}$} & \multirow{2}{*}{$\begin{array}{c}\text { Кількість для } \\
\text { референтних } \\
\text { рівнів АЕС } \\
\text { (2014) }\end{array}$} & \multicolumn{2}{|c|}{$\begin{array}{c}\text { Перед зовнішнім } \\
\text { обговоренням }\end{array}$} & \multirow{2}{*}{$\begin{array}{c}\text { Кількість } \\
\text { референтних } \\
\text { рівнів для } \\
\text { зовнішнього } \\
\text { обговорення }\end{array}$} & \multicolumn{2}{|c|}{$\begin{array}{c}\text { Результати } \\
\text { зовнішнього } \\
\text { обговорення }\end{array}$} & \multirow{2}{*}{$\begin{array}{c}\text { Остаточна } \\
\text { кількість } \\
\text { референтних } \\
\text { рівнів для } \\
\text { дяУ }\end{array}$} \\
\hline & & Додано & Видалено & & Додано & Видалено & \\
\hline$A$ & 9 & 0 & 1 & 8 & 1 & 0 & 9 \\
\hline B & 15 & 0 & 0 & 15 & 0 & 0 & 15 \\
\hline $\mathrm{C}$ & 26 & 0 & 0 & 26 & 0 & 0 & 33 \\
\hline $\mathrm{D}$ & 15 & 0 & 0 & 15 & 0 & 2 & 13 \\
\hline$E$ & 46 & 0 & 3 & 43 & 0 & 1 & 42 \\
\hline $\mathrm{F}$ & 25 & 1 & 3 & 23 & 1 & 1 & 23 \\
\hline G & 7 & 0 & 0 & 7 & 0 & 0 & 7 \\
\hline $\mathrm{H}$ & 19 & 1 & 0 & 20 & 0 & 1 & 19 \\
\hline I & 8 & 2 & 2 & 8 & 0 & 0 & 8 \\
\hline$J$ & 16 & 0 & 0 & 16 & 0 & 0 & 16 \\
\hline K & 20 & 0 & 1 & 19 & 0 & 0 & 19 \\
\hline LM & 20 & 0 & 0 & 20 & 0 & 0 & 20 \\
\hline $\mathrm{N}$ & 17 & 0 & 0 & 17 & 0 & 0 & 17 \\
\hline $\mathrm{O}$ & 16 & 0 & 15 & 1 & 0 & 0 & 1 \\
\hline$P$ & 9 & 0 & 0 & 9 & 0 & 0 & 9 \\
\hline $\mathrm{Q}$ & 15 & 0 & 0 & 15 & 0 & 0 & 15 \\
\hline $\mathrm{R}$ & 20 & 0 & 2 & 18 & 2 & 0 & 20 \\
\hline$S$ & 20 & 0 & 1 & 19 & 0 & 0 & 19 \\
\hline $\mathrm{T}$ & 19 & 0 & 1 & 18 & 1 & 0 & 19 \\
\hline$x$ & 0 & 6 & 0 & 6 & 1 & 0 & 7 \\
\hline Загалом & 342 & 10 & 29 & 323 & 6 & 5 & $331^{*}$ \\
\hline
\end{tabular}

* з урахуванням останніх оновлень, опублікованих RHWG [10] для груп «С» - «Система управління» та «|» - «Управління старінням»

\section{Список використаної літератури}

1. WENRA / Державна інспекція ядерного регулювання України. URL: https://snriu.gov.ua/diyalnist/mizhnarodnadiyalnist/spivrobitnictvo-z-mizhnarodnimi-organizaciyami/ wenra.

2. База даних МАГАТЕ щодо дослідницьких реакторів. MAГATE, 2020. URL: http://nucleus.iaea.org/RRDB/RR.

3. Minutes of $31^{\text {st }}$ meeting of ENSREG. 24 ${ }^{\text {th }}$ November 2015. Luxembourg.
4. Report WENRA. Safety Reference Levels for Existing Reactors. Update in relation to lessons learned from TEPCO Fukushima Dai-ichi accident. WENRA RHWG. $24^{\text {th }}$ September 2014.

5. Preparedness and Response for a Nuclear or Radiological Emergency. IAEA Safety Standards Series, General Safety Requirements No. GSR Part 7. Vienna: IAEA, 2015. 102 p.

6. Use of a Graded Approach in the Application of the Safety Requirements for Research Reactors. IAEA Safety Standards Series, Specific Safety Guide No. SSG-22. Vienna: IAEA, 2012. $74 \mathrm{p}$. 
7. WENRA Ad Hoc Working Group on Reference Levels for Research Reactors. Minutes of meeting, 28-29-09-2017, Brussels, Belgium.

8. Safety of research reactors. IAEA Safety Standards Series, Specific Safety Requirements No. SSR-3. Vienna: IAEA, 2016.125 p.

9. WENRA Ad Hoc Working Group on Reference Levels for Research Reactors. Minutes of $9^{\text {th }}$ meeting, 11-02-14-02-2020, Vienna, Austria.

10. Report WENRA. Safety Reference Levels for Existing Reactors. Update in relation to lessons learned from TEPCO Fukushima Daiichi accident. WENRA RHWG. 2020.

11. Report WENRA. Safety Reference Levels for Existing Research Reactors. WENRA WGRR. November 2020.

\section{References}

1. WENRA / State Nuclear Regulatory Inspectorate of Ukraine. URL: https://snriu.gov.ua/diyalnist/mizhnarodnadiyalnist/spivrobitnictvo-z-mizhnarodnimi-organizaciyami/ wenra.

2. The IAEA's Research Reactor Database (RRDB). IAEA, 2020. URL: http://nucleus.iaea.org/RRDB/RR.

3. Minutes of $31^{\text {st }}$ meeting of ENSREG. $24^{\text {th }}$ November 2015. Luxembourg.

4. Report WENRA. Safety Reference Levels for Existing Reactors. Update in relation to lessons learned from TEPCO Fukushima Dai-ichi accident. WENRA RHWG. $24^{\text {th }}$ September 2014.

5. Preparedness and Response for a Nuclear or Radiological Emergency. IAEA Safety Standards Series, General Safety Requirements No. GSR Part 7. Vienna: IAEA, 2015. 102 p.

6. Use of a Graded Approach in the Application of the Safety Requirements for Research Reactors. IAEA Safety Standards Series, Specific Safety Guide No. SSG-22. Vienna: IAEA, 2012. $74 \mathrm{p}$.

7. WENRA Ad Hoc Working Group on Reference Levels for Research Reactors. Minutes of meeting, 28-29-09-2017, Brussels, Belgium.

8. Safety of Research Reactors. IAEA Safety Standards Series, Specific Safety Requirements No. SSR-3. Vienna, IAEA, 2016. $125 \mathrm{p}$.

9. WENRA Ad Hoc Working Group on Reference Levels for Research Reactors. Minutes of $9^{\text {th }}$ meeting, 11-02-14-02-2020, Vienna, Austria.

10. Report WENRA. Safety Reference Levels for Existing Reactors. Update in relation to lessons learned from TEPCO Fukushima Daiichi accident. WENRA RHWG. 2020.

11. Report WENRA. Safety Reference Levels for Existing Research Reactors. WENRA WGRR. November 2020.

\section{Approaches to the Development of Safety Reference Levels for the Research Reactor of the Western European Nuclear Regulators Association (WENRA)}

\author{
Shepitchak A. ', Kukhotskyi 0. ${ }^{2}$, Ligotskyy 0. ${ }^{2}$, \\ Kulman O. $^{2}$ \\ ${ }^{1}$ State Nuclear Regulatory Inspectorate of \\ Ukraine, Kyiv, Ukraine \\ ${ }^{2}$ State Enterprise «State Scientific and Technical \\ Center for Nuclear and Radiation safety», Kyiv, \\ Ukraine
}

The principal aim of the Western European Nuclear Regulators' Association (WENRA) is to develop a harmonized approach to nuclear safety within the member countries. One of the first major achievements to this end was the publication of Safety Reference Levels (RLs) in 2006 for operating nuclear power plants (NPPs). Based on the lessons learned from the TEPCO Fukushima-Daiichi accident, results of the stress tests, and commitment to continuous improvement of safety, WENRA updated the RLs for NPPs in 2014. During its 31st meeting, the European Nuclear Safety Regulators Group (ENSREG) requested WENRA to develop Safety Reference Levels for Research Reactors (SRLs for RRs). Following this request, during the 2016 spring meeting in Vienna, WENRA decided to develop Safety Reference Levels for Research Reactors through the establishment of an Ad-Hoc Working Group (WGRR). The Dutch regulatory body ANVS accepted to lead this group. It was decided to start up the group and the work in the first half of 2017, as proposed by ANVS. Belgium, France, and Germany were the first countries declaring their participation. Ukraine, as a member of WENRA, joined the working group consisting of experts from the State Nuclear Regulatory Inspectorate of Ukraine (SNRIU) and the State Enterprise «State Scientific and Technical Center for Nuclear and Radiation Safety» (SSTC NRS). The main objective of the WGRR was to develop SRLs for RR. By issuing these RLs for RRs, WENRA aims at further convergence of national requirements and safety improvements in WENRA member countries, as necessary. This is the first article of a series focusing on the harmonization of requirements for research reactors. In this article, the authors present the prerequisites for the establishment of WGRR, define its main tasks, and describe approaches to the development of SRLs for RRs.

Keywords: WENRA, safety, requirements, research reactors, nuclear installation. 